\title{
Solar Cost Reduction Through Technical Improvements: The Concepts of Learning and Experience
}

Frank Krawiec

Theresa Flaim
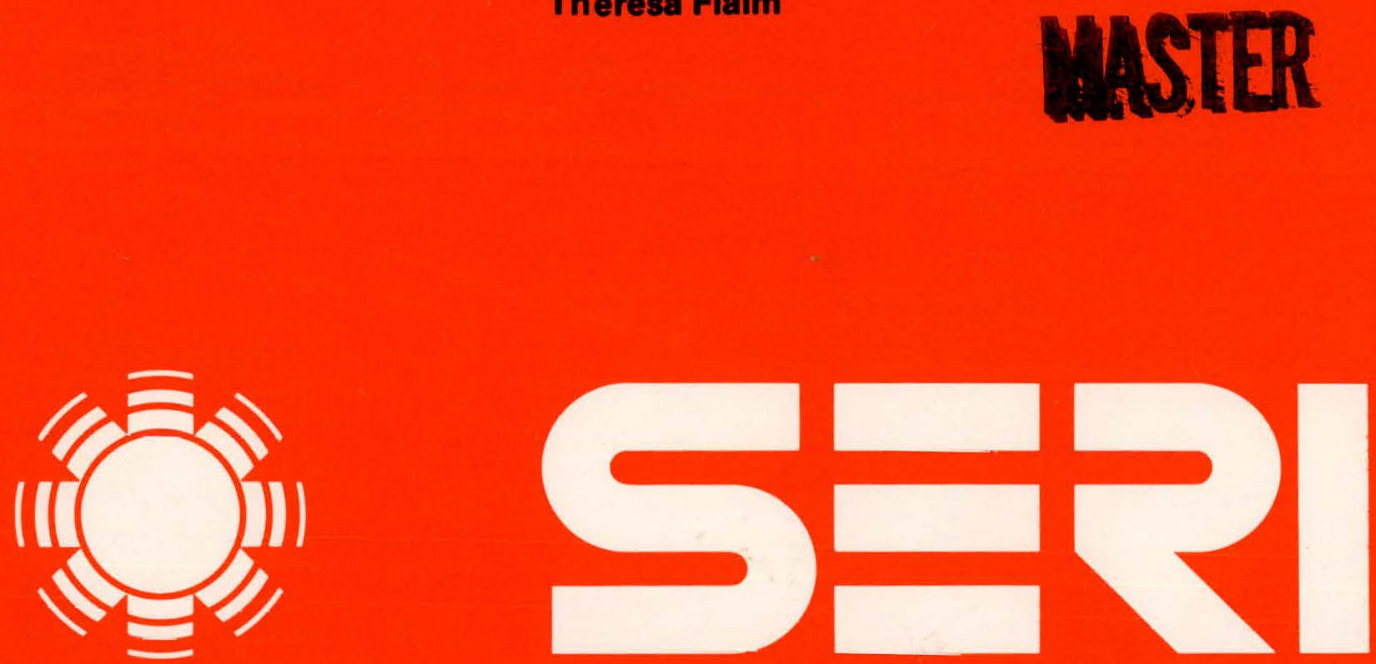

Solar Energy Research Institute

A Division of Midwest Research Institute

1536 Cole Boulevard

Golden, Colorado 80401

Operated for the

U.S. Department of Energy under Contract No. EG-77-C-01-4042

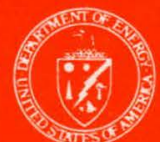




\section{DISCLAIMER}

This report was prepared as an account of work sponsored by an agency of the United States Government. Neither the United States Government nor any agency Thereof, nor any of their employees, makes any warranty, express or implied, or assumes any legal liability or responsibility for the accuracy, completeness, or usefulness of any information, apparatus, product, or process disclosed, or represents that its use would not infringe privately owned rights. Reference herein to any specific commercial product, process, or service by trade name, trademark, manufacturer, or otherwise does not necessarily constitute or imply its endorsement, recommendation, or favoring by the United States Government or any agency thereof. The views and opinions of authors expressed herein do not necessarily state or reflect those of the United States Government or any agency thereof. 


\section{DISCLAIMER}

Portions of this document may be illegible in electronic image products. Images are produced from the best available original document. 


\author{
Printed in the United States of America \\ Available from: \\ National Technical Information Service \\ U.S. Department of Commerce \\ 5285 Port Royal Road \\ Springfield, VA 22161 \\ Price: \\ Microfiche $\$ 3.00$ \\ Printed Copy $\$ 4.50$
}

\begin{abstract}
NOTICE
This report was prepared as an account of work sponsored by the United States Government. Neither the United States nor the United States Department of Energy, nor any of their employees, nor any of their contractors, subcontractors, or their employees, makes any warranty, express or implied, or assumes any legal liability or responsibility for the accuracy, completeness or usefulness of any information, apparatus, product or process disclosed, or represents that its use would not infringe privately owned rights.
\end{abstract}




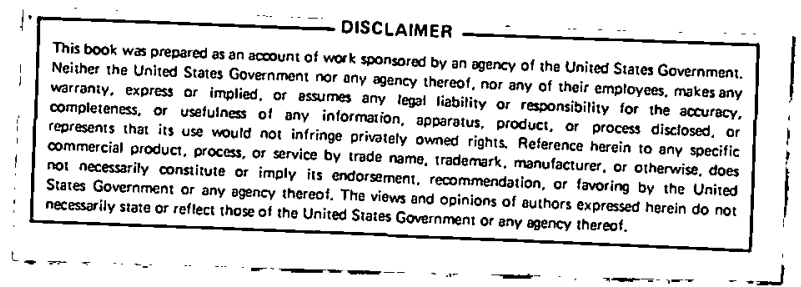

SOLAR COST REDUCTION THROUGH TECHNICAL IMPROVEMENTS : THE CONCEPTS OF LEARNING AND EXPERIENCE

FRANK KRAWIEC THERESA FLAIM

OCTOBER 1979

PREPARED UNDER TASK NO. 5227

\section{Solar Energy Research Institute}

1536 Cole Boulevard

Golden, Colorado 80401

A Division of Midwest Research Institute

Prepared for the

U.S. Department of Energy

Contract No. EG $\cdot 77 \cdot C \cdot 01 \cdot 4042$ 
THIS PAGE

\section{WAS INTENTIONALLY LEFT BLANK}




\section{FOREWORD}

This research report reviews literature on learning and experience curves. It is organized into five sections. First, the factors affecting initial production costs and the procedures for estimating learning curves and for developing cost estimates are examined. Then, the concept of experience and its applicability to cost estimation are discussed. Next, the procedures for developing learning and cost curves for solar technologies are outlined. Finally, a summary and conclusions are presented. The review ascertains whether learning and experience concepts can be effectively applied to predict future costs of solar energy technologies.

Primary SERI staff contributing to this report were Frank Krawiec (Project Leader and Investigator) and Theresa Flaim (Principal Investigator). Assistance was provided by Dennis Costello, James Doane, David Posner, Dennis Schiffel, and Melvin Simmons. The report was prepared as part of a SERI task, "Investigation of Learning and Experience Curves," for the Division of Energy Technology of the U.S. Department of Energy (Task No. 5227).

The authors wish to express appreciation for the helpful comments and suggestions of John Bigger (EPRI); Kirk. Drumheller (Battelle); and Kenneth Brown and Joe Lavender of SERI, Systems Analysis Branch.

Approved for:

SOLAR ENERGY RESEARCH INSTITUTE
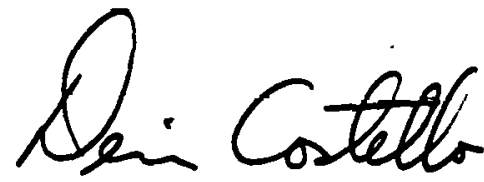

Dennis Costello, Chief

Economic Analysis Branch 
THIS PAGE

WAS INTENTIONALLY

LEFT BLANK 


\section{TABLE OF CONTENTS}

Page

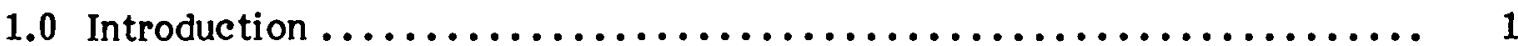

2.0 The Learning Concept $\ldots \ldots \ldots \ldots \ldots \ldots \ldots \ldots \ldots \ldots \ldots \ldots \ldots \ldots \ldots \ldots \ldots$

2.1 Factors Affecting Initial Production Costs ................ 3

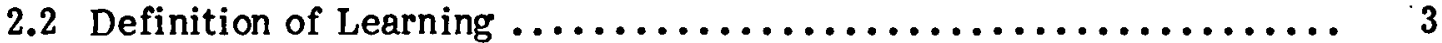

2.3 Learning Curves ............................... 5

2.4 Procedures for Estimating Learning Curves ................. 6

2.5 Applications of Learning Curves....................... 9

2.6 Learning Curves and Cost Estimation ................... 9

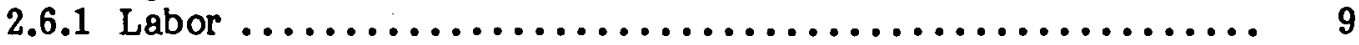

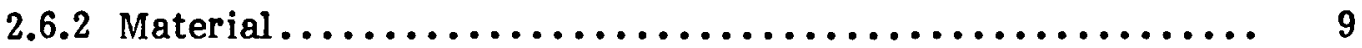

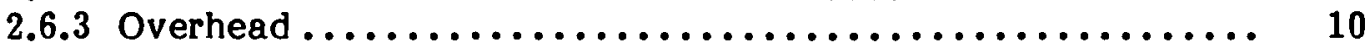

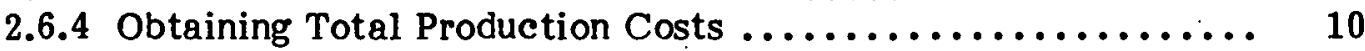

2.7 Limitations of Learning Curves $\ldots \ldots \ldots \ldots \ldots \ldots \ldots \ldots \ldots \ldots \ldots \ldots \ldots$

3.0 The Concept of Experience $\ldots \ldots \ldots \ldots \ldots \ldots \ldots \ldots \ldots \ldots \ldots \ldots \ldots \ldots \ldots$

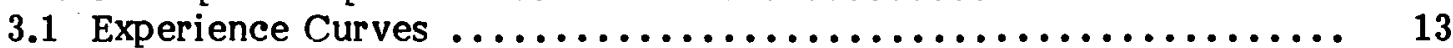

3.2 Applications of Experience Curves..................... 13

3.3 Experience Curves and Cost Estimation ..................... 14

4.0 Developing Learning Curves and Cost Estimates

for Solar Technologies . ............................ 19

4.1 Data Problems .................................... 19

4.2 Estimating Learning Curves for Surrogate Products ............. 19

4.3 Using Learning Curves to Estimate the Costs of Heliostats ............................... 20

5.0 Summary and Conclusions $\ldots \ldots \ldots \ldots \ldots \ldots \ldots \ldots \ldots \ldots \ldots \ldots \ldots \ldots \ldots \ldots$

6.0 References $\ldots \ldots \ldots \ldots \ldots \ldots \ldots \ldots \ldots \ldots \ldots \ldots \ldots \ldots \ldots \ldots \ldots \ldots \ldots \ldots \ldots$ 


\section{THIS PAGE}

\section{WAS INTENTIONALLY \\ LEFT BLANK}




\section{LIST OF PIGURES}

Page

2-1 Hypothetical Unit Learning Curve on Arithmetic Coordinates

2-2 Hypothetical Unit Learning Curve on Logarithmic

Coordinates

\section{LIST OF TABLES}

3-1 Experience Curves (Cumulative Industry Production

vs. Price) Identified by the Boston Consulting Group 


\section{SECTION 1.0}

\section{INTRODUCTION}

Given current methods of producing solar equipment, many solar technology applications are more expensive than conventional energy supply systems. An assessment of future solar energy costs,* particularly of the potential to reduce costs through improvements in production processes, is necessary for several reasons. First, an assessment of solar technologies with the greatest potential for cost reduction would help establish research and development priorities. Second, such an assessment is useful for designing and evaluating government programs to accelerate the commercialization of solar energy. Finally, identifying possible reductions in costs leads to more accurate assessments of the potential market for solar energy. It is for these reasons that methods of estimating and predicting costs are important.

Although there are many different approaches to cost estimation, they will not be described in detail here. (Eugene Grant et al. and E. J. Mishan offer a broader description of problems and approaches to cost estimation [1,2].) Cost estimates for solar energy technologies typically are made assuming a fixed production process that is characterized by standard capacity factors, overhead, and labor costs. Analyzing how variation in the production process may affect cost is useful for identifying potential sources of cost reduction both within and among production processes.

The concepts of learning and experience have been developed in the business management and industrial economics literature as methods of explaining cost reductions which were observed to occur in some industries; learning and experience curves were developed in order to estimate the magnitude of reduction in costs [3,4]. In the broadest sense, the concepts of learning and experience are based on the premise that, as people gain experience with methods of producing a particular product, improvements will be identified and implemented. Reductions in per unit costs have been observed with such regularity in some industries that a number of authors believe that costs can be expected to decrease at some constant, estimable proportion of cumulative production $[5,6]$. Because the solar industry is relatively new, it could be argued that costs will decline as firms gain experience with different methods of producing solar energy equipment. Consequently, the objectives of this report are to review the concepts of learning and experience and to evaluate their usefulness for predicting the future costs of solar technologies.

Sec. 2.0 on the learning concept includes a discussion of the factors affecting initial production costs, and describes the procedures for estimating learning curves and developing cost estimates. The concept of experience and its applicability to cost estimation are described in Sec. 3.0. Sec. 4.0 outlines the procedures for developing learning curves and cost estimates for solar technologies. Sec. 5.0 contains the summary and conclusions.

*Cost refers strictly to market cost in constant dollars, unless otherwise noted. 
SER1* 


\section{SECTION 2.0}

\section{THE LEARNING CONCEPT}

Improvements in production techniques usually occur gradually, and identifying particular improvements and their impacts on cost can be difficult. The learning concept was developed as a method of explaining the general improvements observed in many manufacturing industries. The factors affecting the initial costs of new production processes* are discussed in this section. Then, the concept of learning and the procedures for estimating learning curves are described.

\subsection{FACTORS AFPECTING INTTAL PRODUCTION COSTS}

Production costs of processes which are in the early stages of operation are basically determined by a firm's preproduction planning efforts and investment decisions, which are limited by the firm's technical knowledge. A firm's technical knowledge is affected by the extent to which best-practice technology has been developed in the industry as a whole, the firm's familiarity with existing technology, and the firm's own research and development efforts. Knowledge of product design is also important because it directly affects the production process and because any changes in product design made after operations begin affect production costs.

Preproduction planning efforts and investment decisions involve translating technical knowledge into a working production operation, based upon economic factors (Obviously, if the best-practice technology requires a volume of production greater than the firm's expected sales, other production methods may be desirable.) Preproduction planning involves activities such as purchasing equipment, tooling, organizing assembly operations, scheduling deliveries of materials, etc. Once investments in plant and equipment are made, improvements in the production process are limited by the nature of the equipment [7, p. 17].

To a certain extent, it is useful to consider a firm's technical knowledge as a fixed endowment embodied in its managerial labor, much the way technology is embedded in machines. This fixed endowment can be upgraded by preproduction efforts, or by trial and error after production operations begin. The second option is discussed below as learning by managerial labor.

\subsection{DEFINITION OF LEARNING}

A number of authors have used different definitions of the learning concept [3, pp. 25-27; 8, p. 24]. Winf red Hirschman, for example, used the term to refer generally to technical improvements of all types [5, p. 128]. Most authors, however, use the term to refer to increased labor efficiency resulting from trial-and-error learning af ter production operations begin $[3,4,9,10,11]$. This definition will be used here because of the conceptual and empirical ambiguity created by broader definitions. (Problems associated with attempting to predict cost reduction using an ambiguous definition of learning or

\footnotetext{
*A production process is defined as any combination of inputs producing some output.
} 
experience are described in detail in Sec. 3.0.) The learning concept will be further limited to changes in labor hours required to perform production operations in the shortrun.*

Werner Hirsch compares the learning concept to concepts typically used in economic analysis. He points out that in economic analysis, long-run cost functions permit changes in the size and kind of plant but assume stability in technical knowledge. "Thus, a longrun cost function is related to points on different production functions, each point involving a different plant while using the same techniral knnwledge." Hirseh dcfinc3 production functions as those "which express the net relation between the input of variable production. factors and output during a given production period, under the assumption of a given plant and technical knowledge." In this context, a learning function would be one "which permits changes in technical knowledge, but not in plant and other facilities." Given that labor is the input under consideration, the learning function "expresses the net relation between the amount of direct labor needed to produre one product-unit and the cumulative units produced in a given facility." The learning function, then, is "related to a number of points on different production functions involving successive changes in technical knowledge in a given facility" [9, p. 143].

Increased labor efficiency will occur as the result of learning by direct (operator) labor or by managerial labor. As direct laborers repeat an operation many times, they may become more efficient and the time required to perform the operation may decline. Managers may learn to improve overall production efficiency by eliminating bottlenecks and interruptions, rescheduling material deliveries, improving engineering, and so forth. Learning will usually be most dramatic during the initial stages of production, and productivity will eventually reach a steady state where further improvements will require longer-term adjustments in the production process $[11 ; 12$, p. 45].

Conway and Schultz argue that managerial learning is a more important source of cost reduction than direct labor learning in most industries. They state:

Contrary to the opinion of many ... reporters, it is believed that operator learning in the true sense of perfurmance of a fixed task is of negligible importance in most manufacturing progress.... tooling, flow and methods of changes along with product design changes have been found much more significant. Such changes are usually the result of management and engineering effort rather than operator learning in any sense. [1 ?, $p .42]$

Although learning can occur in any industry, the results of learning have been conspicuous in labor-intensive industries such as the aircraft, apparel, and automobile manufacturing industrles. Within these types of industries, changes in labor productivity have been so regular that learning curves have been estimated.

*The short-run is defined as that period of time in which the capital stock (investment in plant and equipment) is fixed. Learning is defined as a short-run phenomenon because including longer-term changes in the concept makes it difficult to identify separate sources of cost reduction. See Sec. 3.0. 


\subsection{LEARNING CURVES}

Learning curves relate labor hours per unit of output to cumulative production. The functional form which best summarizes this relationship has been a subject of debate. Several authors have contended that the exponential function frequently used to describe learning is inadequate, and they have proposed alternatives such as a $\log$ quadratic function. Orsini summarizes this debate, the results of which have been inconclusive [14, pp. 24-30]. He recommends that analysts select the functional form which best meets their needs $[4, \mathrm{p} .30]$. The most widely used functional form of the learning curve $[11,12]$ is:

$$
\mathrm{y}_{\mathrm{x}}=\mathrm{ax}^{-\mathrm{b}}
$$

where $y_{x}=$ labor hours required to produce the $x$ th unit of production,

$\mathbf{x}=$ cumulative production, between 1 st and $\mathrm{xth}$ units,

$a=$ estimated labor hours required to produce the 1 st unit, and

$b=a$ measure of the rate of reduction in labor hours required to produce the lst unit.

The logarithmic transformation of Eq. 1 is:

$$
\log y_{x}=\log a-b \log x
$$

which is a straight line when graphed on logarithmic coordinates. Fig. 2-1 portrays a hypothetical learning curve of this form on arithmetic coordinates; Fig. 2-2 illustrates the same curve on logarithmic coordinates.

The learning curve obviously applies only to the range of production over which learning occurs [10, 11, 12]. Empirical data show that productivity reaches a steady state $[11,12]$. In practice, the steady-state phase (minimum labor input required after all learning has occurred) should be estimated separately [11, pp. 330-331]. The start-up and steady-state phases are illustrated in Figs. 2-1 and 2-2.

Although a distinction is made between operator and managerial learning, the learning curve necessarily measures the combined effects of both. "To this extent, the learning curve is ... (unly) an empirical method for charting all the various forces which work on labor-hour input" [10, p. 89].

Parameter $\underline{b}$ of the learning curve is an estimate of the reduction in labor input associated with an increase in cumulative production. Another index of learning is frequently calculated: "the percent of learning that occurs each time output is doubled" [11, p. 330]. This index is of ten referred to as the "slope" of the learning curve. Baloff calls it the progress index (PI) $[11$, p. 330] and it is calculated as follows:

$$
\begin{aligned}
& \text { for } \mathrm{x}_{2}=2 \mathrm{x}_{1} \\
& \text { PI }=\frac{\mathrm{y}_{2}}{\mathrm{y}_{1}}=\frac{\mathrm{ax}_{2}^{-b}}{\mathrm{ax}_{1}^{-b}}=2^{-\mathrm{b}}
\end{aligned}
$$


Thus, if an estimated learning curve has $a b$ value of -0.322 , its PI would be 0.80 $\left(2^{-0.322}=0.80\right)$. This indicates that if cumulative production is doubled, the labor input required per unit of output would be $80 \%$ of its former value.

The learning curve defined above is a unit learning curve. Some authors have used a cumulative average curve $[12$, p. 40$]$;

$$
\bar{y}_{x}=\frac{\beta}{N} \sum_{n=1}^{N} x^{-b}
$$

where $\quad \bar{y}_{x}=$ cumulative average labor input per unit, averaged over all units of production from the first to the $\mathrm{Nth}$.

$n=$ the production count $(n=1,2, \ldots N)$.

$x=$ the cumulative production from the first to the Nth.

All other symbols are the same as in Eq. 1.

for values of $X$ greater than 100 , Eq. 4 can be approximated by [12, p. 40]:

$$
\overline{\bar{y}}_{x}=\frac{a x^{-b}}{1-b}
$$

where all symbols are the same as in Eq. 4.

Conway and Schultz observed that the choice between the unit curve and the cumulative average curve has been based largely upon computation convenience. Further, "Since .... the two curves are parallel for large quantities of production the difference is important only during the initial stages of production and hence, for many applications, not crucial" [12, p. 41]. However, after examining industry data, they conclude:

Use of the unit curve rather than the cumulative average curve will be found more illuminating and will provide the same amount of information. The average curve serves to dampen out variation to such an extent that major changes are obscured and ... it is important that the full amount of such variation be obvious. [12, p. 53].

Analysts using the cumulative average curve should be aware that averaging may smooth out important variations in the data. Subsequent discussions of learning curves in this report refer to unit curves unless otherwise noted.

\subsection{PROCEDURES FOR ESTIMATING LEARNING CURVES}

Estimating learning curves involves several steps: (1) specifying the functional form of the equation to be estimated, (2) data collection, and (3) estimation. The exponential function is the most widely used functional form. This form is intuitively appealing because it reflects the fact that, in some industries, progress is rapid during the early stages of production and continues at a decreasing rate $[10$, p. 89$]$. However, since the 


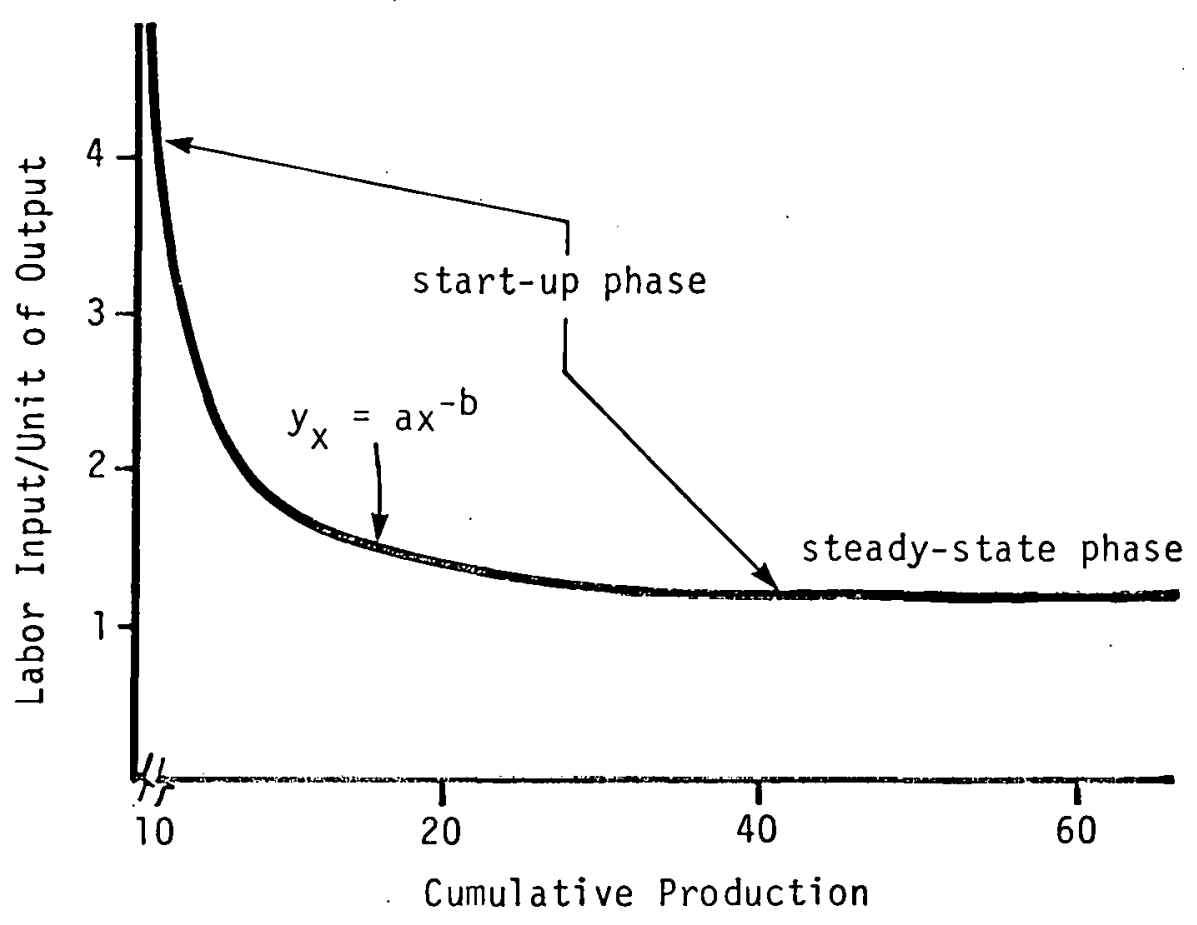

Figure 2-1. Hypothetical Unit Learning Curve on Arithemetic Coordinates.

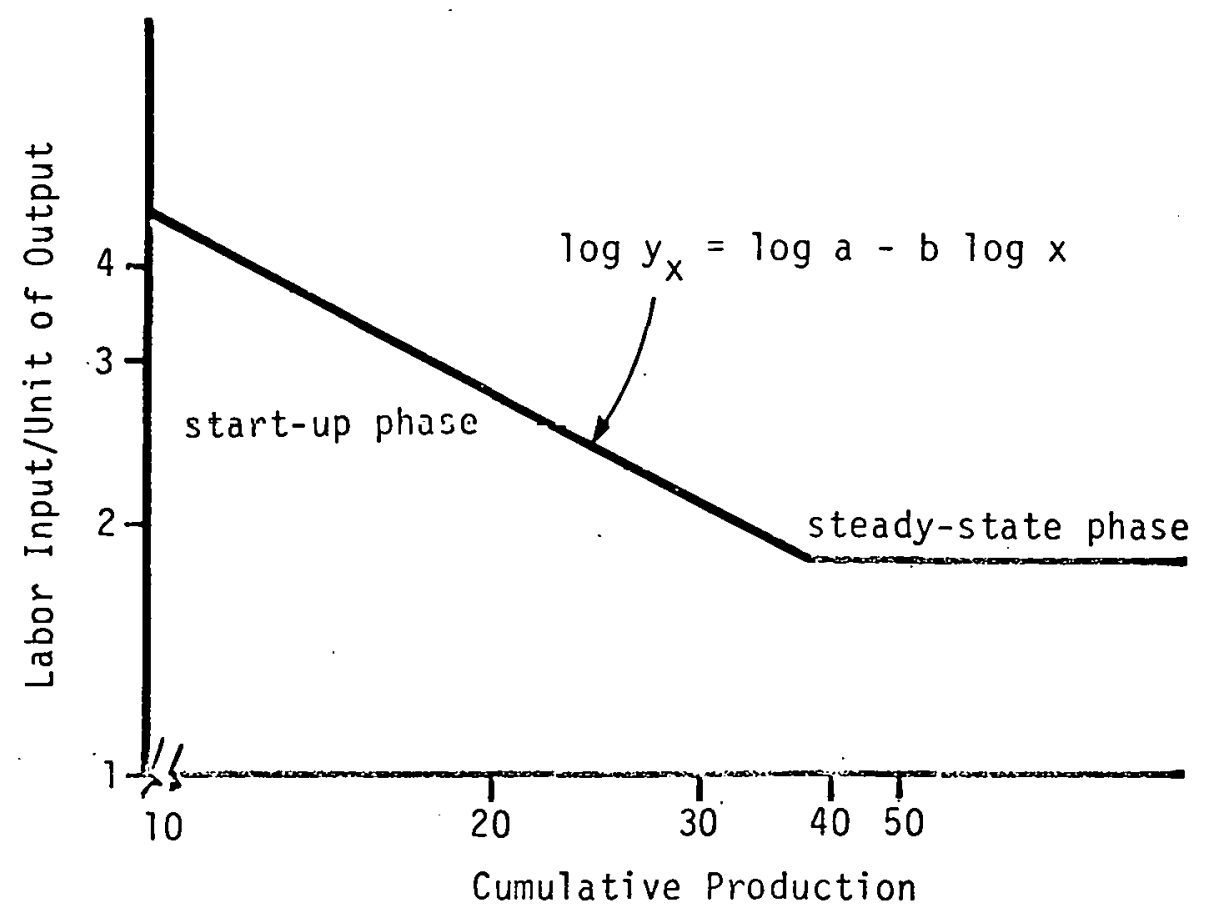

Figure 2-2. Hypothetical Unit Learning Curve on Logarithmic Coordinates. 
logic behind the learning concept does not suggest a particular functional form, analysts should specify an equation which best summarizes the data.

Probably the most difficult problem associated with estimating learning curves is obtaining data. Conway and Schultz describe problems associated with aggregation and data accuracy. They point out that a learning curve for a particular product applies to a series of parts, components, suboperations, and assembly operations. The analyst must determine which items are to be aggregated and decide how those items should be aggregated. Data accuracy is also a serious problem because labor hours may not be acurately recorded and obtaining an accurate production count can be difficult [12, p. 43]. Conway and Schultz comment that it was rarely possible to calculate the actual cost of the first unit of production, but that "its use as a basic parameter to locate the function is not necessarily advisable." Instead, they recommend that the function be estimated from data based upon some conception of stabilized production volume [12, p. 44]. This proce dure contrasts with trying to calculate the actual cost of the first unit of production, and then applying a. "standard" learning curve to predict the reduction in labor hours. The latter process has been used in the aircraft industry [12, p. 44] but is not recommended by Conway and Schultz because their research indicates that a universal rate of learning does not exist $[12$, p. 53].

Proper aggregation of assembly operations is necessary not only to obtain complete data for a product's leaming curve, but also for estimation purposes. Conway and Schultz point out that if the exponential learning curve (which is linear in logs) is assumed to hold for each suboperation in a product's manufacture, it cannot normally be assumed to hold for the total as well. If a single product is represented by two operations, the learning curves for which are:

$$
\begin{aligned}
& y_{1 x}=a_{1} x^{-b l} \\
& y_{2 x}=a_{2} x^{-b 2}
\end{aligned}
$$

the plot of $\left(y_{1 x}+y_{2 x}\right)$ against $x$ on $\log$ coordinates "is a convex curve whose shape depends upon the four values ... [a $a_{1}, a_{2}, b_{1}$, and $\left.b_{2}\right]$. The plot will be a straight line if, and only if, $b_{1}=b_{2}=b^{\prime \prime}[12, p .41]$. In other words, the sum of the learning curves for each suboperation will be a straight line on logarithmic coordinates providing that the rate of learning is the same for both operations, which is not generally the case. The analyst must decide whether the exponential learning curve applies to each suboperation or to total operations, because theoretically the curve can apply tn nnly nne level [1 2, p. 41].

From a practical point of view, aggregating learning curves for processes involves complex calculations. If analysts decide to use the exponential function for each suboperation and to apply it to the sum for convenlence, they should realize that doing so will result in errors in computation.

Once the equation is specified and the necessary data are obtained and aggregated, the parameters can be estimated by using regression techniques. The start-up and steadystate phases should be estimated separately because the steady-state phase appears as an interr uption of the learning curve [11, p. 330] . 


\subsection{APPLICATIONS OF LEARNING CURVBS}

The learning curve was developed as a managerial planning tool. It has been used as a basis for facilities and manpower scheduling, pacing assembly operations, and cost estimation [12, p. 50]. Cost estimates obtained through learning curves have been used as the basis for contract negotiations in the aircraft industry, and for a variety of pricing, buying, and financing decisions [10, pp. 91-95]. The use of learning curves for cost estimation is of primary interest.

\subsection{LEARNING CURVES AND COST ESTIMATION}

Estimated learning curves can be used to predict a manufacturer's costs. At the center of empirical studies is the concept of separating labor, material, and overhead costs, the factors that make possible cost reductions and concomitant increases in the quantity produced. Prediction of labor costs will be discussed first; next, the estimation of the parameters of the curve for materials and overhead costs will be considered; then, the procedures for obtaining total product costs will be outlined. Finally, the limitations of learning curves will be addressed.

\subsubsection{Labor}

A learning curve indicates the relationship between labor input (measured in labor hours per unit of output) and cumulative production. But in order to determine labor costs, labor hours must be multiplied by appropriate wage rates. Even though some authors have used learning curves to predict labor costs directly [13, 14], labor hours and wage rates should be calculated separately for several reasons.

First, economic theory suggests that as the productivity of an input increases, its wage rate should also increase [15, pp. 293-307]. Second, for some of the industries examined, Conway and Schultz found that progress in labor hours was roughly offset by rising hourly wages and that labor costs were less predictable than hours [12, p. 49]. They state:

Use of a labor hour or a machine hour base has been found to be much more illuminating than dollar costs. Where dollar costs are desired they may be used as a multiplier, but price changes serve to mask production progress in terms of fundamental resource consumption. [12, p. 53].

Finally, labor hours can be reduced by substituting more skilled and more expensive labor for less skilled workers. But by reducing labor hours, a firm could face higher labor costs [10, p. 90]. For these reasons, labor hours and wage rates must be calculated separately to avoid errors in labor cost predictions.

\subsubsection{Material}

Materials may decrease in cost as production increases. Although the estimation of the parameters of the curve for materials costs has been of significant concern, little has been written concerning reduction in the material component of product cost. Only a few authors have examined material cost reductions due to (1) volume discounts, (2) purchasing in more efficient shapes, or (3) reduction of rejects [13, 18, 21, 22]. Conway and Schultz believe that "there is no reason why one could not quantify past experience and use it to predict reduction in material cost. Lacking such information one would 
probably neglect progress in this area except for obvious economics associated with quantity" [12, p. 51].

\subsubsection{Overhead}

Some empirical studies indicate that amount of overhead varies, within limits, with quantity of output. Overhead is usually expressed as a percentage of direct labor costs which results in a log-linear relationship for overhead costs. Overhead costs fluctuate greatly in different cases depending, for example, on structural components (e.g., taxes, depreciation, executive salaries) or on whenever a particular factory is engaged in the manufacture of one type of product or of many types [18, 21].

\subsubsection{Obtaining Total Produetion Costs}

An aggregated cost curve for direct application to different quantities of the end product can be developed by combining factors of labor, material, and overhead. Wright pointed out that the shape of a total cost curve developed by this method in the aircraft industry "will start out at eighty-three percent, then change to eighty-seven percent, and finally reach ninety percent. This change in slope is an indication of the relatively greater importance of material to labor as quantity increases" [18, p. 126]. This cost estimation procedure is distinctly different from using experience curves to predict total unit costs directly. (See Sec. 3.0 for a discussion of experience curves.)

\subsection{LIMITATIONS OF LEARNING CURVES}

Learning curves can be useful tools for estimating changes in production costs. They have been applied successfully in the aerospace and related defense industries $[10,11,12$, 18]. The relevance of the learning curve in labor extensive manufacture-automobile assembly, apparel manufacture and the production of large musical instruments-was found by Baloff. The usefulness of learning curves for predicting costs in labor-intensive industries has been widely demonstrated [11, p. 339]. There may also be a need for greater generalization and application of the learning curve in capital-intensive industries. Labor learning as defined here may only be a minor source of cost reduction in these types of production activities. However, the literature $[9,10,11,12,18,21]$ does not provide empirical evidence to question the applicability of the learning curve concept in capital-intensive industries. These learning curves are subject to three important limitations.

First, the learning curve is a method of estimating changes in labor productivity that occur after production operations begin. If substantial efforts are devoted to preproductlon englneering and planning and if labor productivity is higher than it otherwise would have been, the learning curve will not capture the progress that has been made.

Second, learning rates vary substantially among industries, firms, products, and types of work $[9,11,12]$. Conway and Schultz conclude: 
There is no such thing as the fundamental law of progress such as the "80\% learning curve"* used in the aircraft industry. No particular slope is universal, and probably there is not even a common model. The contention that such exists is most difficult to defend either. logically or empirically. [12. p. 53]

Analysts must choose the appropriate model and estimate the rate of progress for that product.

Third, the analyst must determine the range of production over which progress will occur. Empirical data show that progress does not continue indefinitely $[11,12,14]$. The application of learning curves is based upon the assumption that progress in labor hours will be achieved over the range of production specified.

*The "80\% learning curve" is identical to the progress index. 


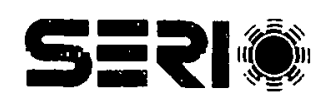




\section{SECTION 3.0}

\section{THE CONCEPT OF EXPERIENCE}

Like the learning concept, the concept of experience was developed from the observation that per-unit production costs declined in some industries as a direct, estimable proportion of cumulative production $[5,6,16]$. Unlike learning that refers to the productivity of a single input, the experience concept has been used to describe changes in total costs as a function of cumulative production.

According to the Boston Consulting Group, which claims to have originated the concept, "The experience ... eff ect .... encompasses all costs (including capital, administrative, research, and marketing) and traces them through technological displacement and product evolution" [6, p. 6]. They state that from their observations of various industries, "costs appear to go down ...20\% to $30 \%$ every time total product experience doubles for the industry as a whole, as well as for individual producers" [6, p. 12]. The experience concept applies to long-term improvements in production processes and includes cost reduction from every conceivable source, including technical improvements, input substitution, economies of scale, new product design, and changing input prices.

\subsection{EXPERIENCE CURVES}

Experience curves are similar to learning curves and are calculated as follows:

$$
c_{x}=a x^{b}
$$

where $\quad c_{x}=$ the cost of producing the $x$ th unit of output,

$\mathbf{x}=$ cumulative production,

a = estimated cost of producing the lst unit, and

$b$ = parameter measuring the change in total cost (normally $-1<b<0$ is assumed).

In practice, the "experience curve" usually refers to the percentage reduction in cost associated with a doubling of cumulative production. It is calculated the same way that the progress index is calculated for learning curves:

$$
\text { for } x_{2}=2 x_{1}, \quad \frac{c_{1}}{c_{2}}=\frac{a x_{2}^{-b}}{a x_{1}^{-b}}=2^{-b} \text {. }
$$

An "80\% experience curve" would indicate that if cumulative production doubles, per unit production cost would decline to $80 \%$ of its level prior to doubling [16, p. 53].

\subsection{APPLICATIONS OF EXPERIENCE CURVES}

The Boston Consulting Group (BGG) examined historical data for 24 products and found that price reductions* were strongly correlated with cumulative production [6, pp. 69- 
101]. Their results were summarized by Costello et al. [8] and are presented in Table 31. Similar data were compiled by Hirschmann [5] and cited by Bodde [16].

These experience curves were not estimated by the BCG to be used directly for cost estimation purposes. Rather, the BCG and other authors cite experience curves as evidence that costs can decline as the result of many factors and recommend that managers are aware of cost reduction possibilities when designing product-market strategies $[5,6,16]$.

\subsection{EXPERIENCE CURVES AND COST ESTIMATION}

Even though cost prediction was not the goal of the Boston Consulting Group, some analysts have attempted to use experience curves to predict the future costs of solar technologies [21, pp. xiv-xv, 159-161]. Despite the statistical evidence that costs have declined historically in some industries, there are serious problems with using experience curves to predict cost reductions.

One problem is that there is no logical reason to believe that costs should decline as a function of cumulative production per se. Stated differently, there is no a priori reason to believe that the parameter $b$ in the experience curve will be negative in sign. It is quite possible that costs may be increasing for a particular product. Long-run costs could increase due to (1) rising input prices, (2) government regulations requiring higher cost production methods, or (3) firms adopting new production methods which result in higher production costs.**

Because the experience curve describes cost changes as a function of cumulative production, a second problem is that there is no way to separate cost changes due to technical progress from those due to falling input prices. Declining input prices clearly influenced cost changes for at least nine of the 24 products cited by the BCG: electricity and the eight petroleum-based products.". Experience curves necessarily reflect the combined effects of both progress and declining input prices, and cannot be interpreted as measures of progress alone.

Separating the influence of technical progress from changing input prices is further complicated by the fact that improvements in production processes are motivated by both new technical knowledge and changing input prices [7, p. 23]. Thus, if a change in the production process is made in order to substitute a cheaper input for a more expensive input, that improvement cannot be expected to apply to a solar technology unless

* Cost data were unavailable; price data were used as proxies for costs. Price changes were measured in constant dollars. In general, prices are inadequate measures of cost because prices are determined by both supply and demand conditions.

**Firms might adopt higher-cost (less optimal) production methods due to imperfect information or risk and uncertainty. In addition, if markets are not price competitive, firms may pursue goals other than cost minimization which could result in higher production costs [17]. Discussion of these factors is beyond the scope of this paper.

" Crude oil prices in constant dollars generally declined from 1950 to 1972 (see Table 3-1). Crude oil is an input to petroleum products; fuels derived from crude oil are used in electricity generation. 
Table 3-1. EXPERIENCE CURVES ${ }^{\mathrm{a}}$ IDENTIFIED BY THE BOSTON CONSULTING GROUP (Cumulative Industry Production vs. Price)

\begin{tabular}{|c|c|c|}
\hline Process or Industry & $\begin{array}{c}\text { Experience Curve } \\
\text { Slope } \\
\text { (Constant Dollars) }\end{array}$ & Data Comments \\
\hline $\begin{array}{l}\text { Germanium Transistors } \\
\text { Industry }\end{array}$ & $\begin{array}{l}90 \%(1954-1960) \\
70 \%(1960-1968)\end{array}$ & $\begin{array}{l}1954-1968 \\
1954-1969\end{array}$ \\
\hline Silicon Transistors Industry & $\begin{array}{l}90 \%(1954-1959) \\
70 \%(1960-1965) \\
80 \%(1965-1969)\end{array}$ & $1954-1969$ \\
\hline Germanium Diodes & $\begin{array}{l}90 \%(1955-1959) \\
70 \%(1960-1968)\end{array}$ & $1955-1968$ \\
\hline Silicon Diodes & $\begin{array}{l}90 \%(1955-1959) \\
70 \%(1960-1968)\end{array}$ & $1955-1968$ \\
\hline Integrated Circuits & $70 \%$ & $\begin{array}{l}1964-1968 \text { (1965 \& } \\
1966 \text { monthly data) }\end{array}$ \\
\hline Crude Oil & $\begin{array}{l}\text { Increasing prices } \\
(1946-1948) \\
90 \%(1948-1958) \\
70 \%(1958-1968)\end{array}$ & $\begin{array}{l}1946-1968 \\
\text { Real prices } \\
\text { increased from } \\
1946-1948\end{array}$ \\
\hline Motor Gasoline & $\begin{array}{l}\text { Prices increased } \\
(1946-1949) \\
90 \%(1949-1957) \\
75 \%(1957-1968)\end{array}$ & $\begin{array}{l}1946-1968 \\
\text { (Average price/gallon } \\
\text { excluding California) } \\
\text { U.S. data only }\end{array}$ \\
\hline Ethylene & $\begin{array}{r}100 \%(1953-1963) \\
70 \%(1963-1968)\end{array}$ & $\begin{array}{l}\text { 1953-1968 } \\
\text { U.S. Tariff Price } \\
\text { vS. U.S. data only }\end{array}$ \\
\hline Benzene & $\begin{array}{l}70 \%(1953-1963) \\
90 \%(1963-1968)\end{array}$ & $\begin{array}{l}\text { 1952-1968 } \\
\text { U.S. data only }\end{array}$ \\
\hline Paraxylene & $\begin{array}{l}90 \%(1957-1961) \\
70 \%(1961-1968)\end{array}$ & $1957-1968$ \\
\hline Low Density Polyethylene & $\begin{array}{l}90 \%(1952-1959) \\
70 \%(1960-1968)\end{array}$ & $1952-1968$ \\
\hline Polypropylene & $\begin{array}{l}90 \%(1959-1961) \\
80 \%(1961-1968)\end{array}$ & $1959-1968$ \\
\hline $\begin{array}{l}\text { Polystyrenc (Gencral Purposc } \\
\text { Molding and Extrusion Resin) }\end{array}$ & $\begin{array}{l}90 \%(1943-1954) \\
70 \%(1954-1968)\end{array}$ & $1943-1968$ \\
\hline Polyvinylchloride & $\begin{array}{l}90 \%(1946-1955) \\
70 \%(1955-1961) \\
80 \%(1961-1968)\end{array}$ & $1946-1968$ \\
\hline
\end{tabular}


Table 3-1. EXPERIENCE CURVES ${ }^{\mathrm{a}}$ IDENTIPIED BY THE BOSTON CONSULTING GROUP (Cumulative Industry Production vs. Price) (concluded)

\begin{tabular}{|c|c|c|}
\hline Process or Industry & $\begin{array}{c}\text { Experience Curve } \\
\text { Slope } \\
\text { (Constant Dollars) }\end{array}$ & Data Comments \\
\hline Primarv Aluminum & $\begin{array}{l}80 \%(1929-1939) \\
70 \%(1939-1948) \\
\text { no trend }(1961-1968)\end{array}$ & $1929-1968$ \\
\hline Primary Magnesium & $80-90 \%$ & $\begin{array}{l}1929-1968 \\
\text { Significant deviations } \\
\text { in trend }\end{array}$ \\
\hline Titanium Sponge & $\begin{array}{r}100 \%(1950-1954) \\
70 \%(1954-1968)\end{array}$ & $\begin{array}{l}1950-1968 \\
\text { Strong deviation } \\
\text { between 1958-1968 }\end{array}$ \\
\hline $\begin{array}{l}\text { Monochrome 'l'elevision } \\
\text { Receivers }\end{array}$ & $\begin{array}{l}90 \%(1947-1954) \\
70 \%(1954-1968)\end{array}$ & $1947-1968$ \\
\hline $\begin{array}{l}\text { Total Freestanding } \\
\text { Gas Ranges }\end{array}$ & $\begin{array}{r}100 \%(1946-1950) \\
70 \%(1951-1967)\end{array}$ & $\begin{array}{l}1946-1967 \\
\text { Average wholesale } \\
\text { price }\end{array}$ \\
\hline $\begin{array}{l}\text { Total Freestanding } \\
\text { Electric Ranges }\end{array}$ & $\begin{array}{l}90 \%(1946-1957) \\
70 \%(1957-1967)\end{array}$ & $1946-1967$ \\
\hline Facial Tissue & $\begin{array}{l}90 \%(1933-1945) \\
\text { increases }(1945-1948) \\
90 \%(1948-1966)\end{array}$ & $1933-1966$ \\
\hline Japanese Beer & $80-90 \%$ & $\begin{array}{l}1951-1968 \\
\text { Retail price } \\
\text { minus indirect tax }\end{array}$ \\
\hline Electric Power & $\begin{array}{l}70 \%(1939-1943) \\
80 \%(1943-1968)\end{array}$ & $1939-1968$ \\
\hline Refined Cane Sugar & $70 \%$ & $\begin{array}{l}1935-1968 \\
\text { Very wide fluc- } \\
\text { tuátions in data }\end{array}$ \\
\hline
\end{tabular}

${ }^{a}$ From Costello et al. [8, pp. 32-33]. Data were compiled from Boston Consulting Group [6, pp. 69-101]. 


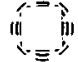

the solar firm faces the same relative input prices.

The third problem involves source identification and analysis. Even though the experience concept as defined by BCG [6] and Bodde [16] includes cost reductions from logical sources, such as technical improvements, sources of cost reduction and their impacts on costs must be analyzed directly. In other words, cost reduction sources must be identified separately and their potential impacts upon costs should be estimated directly. There is no other way to evaluate whether cost reduction sources and their impact on costs can be expected to apply in the production of solar technologies. Without careful analysis of separate sources of cost reductions, experience curves, which are estimated from other product histories and used to predict the future costs of solar technologies, will yield arbitrary and perhaps misleading cost estimates.

Analysts who are using experience curves to predict the costs of solar technologies should heed the advice of the Boston Consulting Group, who originated the concept:

As a practical matter experience curves should be considered only as a means of understanding relationships, not as a measuring device. There are inherently too many difficulties in definition and factor measurement. This applies particularly to the definitions of product and cost as well as measuring accumulated experience. [emphasis added; 6, p. 63]. 


\section{SE尺Р|*}




\section{SECTION 4.0}

\section{DEVELOPING LEARNING CURVES AND COST ESTIMATES FOR SOLAR ENERGY TECHNOLOGIES}

Empirical applications of learning curves have been based upon products for which historical production data are available $[3,4,9,11,12,18,19]$. For new products such as many solar energy technologies, adequate data are not available for estimating learning curves. This section describes the procedures for developing learning curves and cost estimates for new products using surrogate data. The production of heliostats is used as an example.

The heliostat is one of the basic components of solar thermal central receiver systems which can be used to generate electricity or process heat. The heliostat accounts for approximately $50 \%$ of the system's capital cost. Thus, the future costs of heliostats will be a major determinant of a system's cost relative to conventional methods of generating electricity or process heat.

\subsection{DATA PROBLEMS}

Several firms have proposed new heliostat designs that could potentially reduce the cost of heliostats [20]. Future costs of heliostats will depend largely upon the production methods used and the potential for cost reduction through improvements in the production process. Because adequate production data do not exist for directly estimating learning curves for heliostats, examining the production history of similar products or processes may help identify potential improvements in the production process for heliostats.

First, however, it is necessary to define the heliostat production process as clearly as possible by (1) selecting a heliostat design and identifying its major design characteristics, and (2) specifying the production process to be used. Specifying the production process requires estimating the necessary capital stock (investment in plant and equipment), the variable inputs such as materials and labor, and the organization of production activities, including the major processes, subassembly, and assembly operations. This information should be available in the reports describing the proposed heliostat designs [20].

\subsection{ESTIMATTNG LEARNING CURVES FOR SURROGATE PRODUCTS}

Products or production processes which closely resemble the components and production methods of heliostats should be identified. Examining the production history of surrogates is recommended because production data will be available for them and because it is -assumed that "new manufacturing processes are, in many instances, nothing more than an aggregation of well developed operations which can be found in other established manufacturing processes" [19, p. 149].

Obtaining the necessary production data for surrogate products is not an easy task. Except for regulated industries, such data are usually unavailable to the public and obtaining them will probably require access to proprietary data sources. Once the data are obtained, learning curves can be estimated using the procedures outlined in Sec. 2.0. When estimating learning curves the analyst should be careful to distinguish between ( 1 ) 
improvements in labor productivity due to learning, and (2) improvements due to more fundamental changes in the production process, such as a change in the capital stock or in product design. The former would result in a movement along the learning curve and the latter would result in a shift to a new learning curve. In practice, this distinction will be difficult to make. According to Conway and Schultz:

It becomes a matter of judgment to decide when a change is significant enough to justify treatment of the product as a new model, and when it should be treated as normal progress with the current model. [12, p. 43]

\subsection{USING LEARNING CURVES TO ESTIMATE THE COSTS OF HELIOSTATS}

Learning curves for surrogate products should be evaluated in order to determine whether the same rate of progress reasonably can be expected to occur in heliostat. production. In particular, it is necessary to specify the range of cumulative production over which learning occurred in surrogate products and is likely to occur in the production of heliostats. Given these qualifications, the surrogate learning curves can be used to estimate labor requirements for each subassembly, assembly, and process involved in the production of heliostats. Labor hours should then be multiplied by appropriate wage rates to calculate labor costs.

In order to calculate total costs for each process, labor costs must be added to materials, capital, and overhead costs. Material cost reductions in the surrogate product's history should be estimated if they have been significant due to (1) volume discounts, (2) purchasing in more efficient shapes, or (3) reduction of rejects. If the same sources of material cost reduction apply to heliostat components, the analyst may want to adjust material cost estimates accordingly.

A composite heliostat cost curve can be calculated by aggregating total cost estimates for each operation in the production process. An experience curve can be estimated for a product analogous to the heliostat; however, it can be used only to provide a crude indication of long-term changes in the surrogate's production history. The experience curve should not be used to predict heliostat costs directly. 


\section{SECTION 5.0}

\section{SUMMARY AND CONCLUSIONS}

The concepts of learning and experience are reviewed and their usefulness for predicting the future costs of solar technologies are evaluated. The most widely used definition of the learning concept refers to increased labor productivity resulting from trial-and-error learning after production operations begin. That definition is used in this report because broader definitions, particularly those which include technical improvements of all types, are too a mbiguous to be used for cost estimation purposes. To reduce measurement problems, it is argued that the learning concept should be applied to improvements in the production process which occur when the capital stock is fixed. Given these qualifications, learning curves can be a useful tool for estimating potential improvements in production processes. The procedures for estimating learning curves and for using learning curves to calculate labor costs are discussed.

Unlike the concept of learning, the concept of experience is too ambiguous to be useful for cost estimation. There is no logical reason to believe that costs will decline purely as a function of cumulative production, and experience curves do not allow the analyst to identify logical sources of cost reduction directly. Using an experience curve to estimate the future costs of solar technologies will only yield tautological results. All that one can conclude from using an "80\% experience curve" to estimate costs is that if the cost of solar technologies declines $20 \%$ each time cumulative production doubles, then solar technologies will be $20 \%$ less expensive to produce each time cumulative production doubles. Clearly, better methods than experience curves should be used to estimate the future costs of solar technologies, particularly when cost estimates are necessary to help establish solar energy policy.

Finally, the procedures for using learning curves to estimate the costs of solar technologies are outlined. Because adequate production data do not exist for many solar technologies, it is recommended that production histories of analogous products and processes are analyzed and that learning curves for these surrogates are estimated. If the surrogate learning curves are judged applicable, they can be used to estimate the costs of solar technologies. The steps involved in generating these costs estimates are presented. 
SEPI 


\section{SECTION 6.0}

\section{REFERENCES}

1. Grant, Eugene L.; Ireson, Grant W.; Leavenworth, Richard S. Principles of Engineering Economy. 6th ed. New York: The Ronald Press Co.; 1976.

2. Mishan, E. J. Cost-Benefit Analysis. New York: Praeger Publishers; 1973.

3. Colasuonno, Vincent. "An Analysis of Progress Curve Conceptual Advances and Progress Curve Uses Since 1956." M. S. thesis; Air University; 1967.

4. Orsini, Joseph A. "An Analysis of Theorectical and Empirical Advances in Learning Curve Concepts Since 1966." M. S. thesis; Air University; 1970.

5. Hirschmann, Winfred B. "Profit from the Learning Curve." Harvard Business Review. vol. 42: pp. 125-139; January-February 1964.

6. Boston Consulting Group. Perspectives on Experience. Boston: Boston Consulting Group; 1972.

7. Salter, W. E. G. Productivity and Technical Change. 2nd ed. London: Cambridge University Press; 1966.

8. Costello, Dennis; Posner, David; Doane, James; Schiffel, Dennis; Lawrence, Kathryn. Photovoltaic Venture Analysis; Progress Report. SERI-23. Golden, CO: Solar Energy Research Institute; April 1978.

9. Hirsch, Werner F. "Manufacturing Progress Functions." Review of Economics and Statistics. vol. 34: pp. 143-155; May 1952.

10. Andress, Frank J. "The Learning Curve As a Production Tool." Harvard Business Review. vol. 32: pp. 87-97; January-February 1954.

11. Baloff, Nicholas. "Extensions of the Learning Curve: Some Empirical Results." Operational Research Quarterly. vol. 22: pp. 329-340; December 1971.

12. Conway, R. W.; Schultz Jr., Andrew. "The Manufacturing Progress Function." The Journal of Industrial Engineering. vol. 10: pp. 39-54; January-February 1959.

13. Pegels, C. Carls. "Start Up or Learning Curves: Some New Approaches." Decision Sciences. vol. 7: pp. 705-713; 1976.

14. Morse, Wayne J. "Learning Curve Cost Projections with Constant Unit Costs." Managerial Planning. pp. 15-21; March-April 1974.

15. Ferguson, C. E. The Neoclassical Theory of Production and Distribution. London: Cambridge University Press; 1971.

16. Bodde, David L. "Riding the Experience Curve." Technology Review. pp. 53-59; March-April 1976. 
17. Scherer, F. M. Industrial Market Structure and Economic Performance. Chicago, IL: Rand MeNally Publishing Co.; 1970.

18. Wright, T. P. "Factors Affecting the Cost of Airplanes.: Journal of the Aeronautical Science. vol. 1: pp. 122-128; February 1936.

19. Yelle, Louis E. "Estimating Learning Curves for Potential Products." Industrial Marketing Management. vol. 5: pp. 147-154; 1976.

20. MITRE Corporation, METREK Division. Systems Descriptions and Engineering Costs for Solar-Related Technologies: Solar Thermal Electric Systems; Vol 5. MTR7485. McLean, VA: MITRE Corporation; June 1977.

21. Brewer, Glenn M. "The Learning Curve in the Airframe Industry." M. S. thesis; Air University; 1965.

22. Reguero, Miguel, A. "An Economic Study of the Military Airframe Industry". Ann Arbor, Mich. University Microfilms International; 1957. 


\begin{tabular}{|c|c|c|}
\hline $\begin{array}{l}\text { Document Control } \\
\text { Page }\end{array}$ & \begin{tabular}{|l|c} 
1. SERI Report No. & 2. NTIS Accession No. \\
RR-52-173 &
\end{tabular} & 3. Recipient's Accession No: \\
\hline \multirow{3}{*}{\multicolumn{2}{|c|}{$\begin{array}{l}\text { 4. Title and Subtitle } \\
\text { Solar Cost Reduction Through Technical Improvements: } \\
\text { The Concepts of Learning and Experience }\end{array}$}} & \multirow{2}{*}{$\begin{array}{r}\text { 5. Publication Date } \\
\text { October } 1979 \\
\end{array}$} \\
\hline & & \\
\hline & & 6. \\
\hline \multicolumn{2}{|c|}{$\begin{array}{l}\text { 7. Author(s) } \\
\text { Frank Krawiec \& Theresa Flaim }\end{array}$} & 8. Performing Organization Rept. No. \\
\hline \multirow{2}{*}{\multicolumn{2}{|c|}{$\begin{array}{l}\text { 9. Performing Organization Name and Address } \\
\text { Solar Energy Research Insti tute }\end{array}$}} & $\begin{array}{l}\text { 10. Project/Task/Work Unit No. } \\
\text { Task } 5227 \text {. }\end{array}$ \\
\hline & & $\begin{array}{l}\text { 11. Contract (C) or Grant (G) No. } \\
\text { (C) } \\
\text { (G) }\end{array}$ \\
\hline \multirow{2}{*}{\multicolumn{2}{|c|}{ 12. Sponsoring Organization Name and Address }} & $\begin{array}{l}\text { 13. Type of Report \& Period Covered } \\
\text { Research Report }\end{array}$ \\
\hline & & 14. \\
\hline \multicolumn{3}{|l|}{ 15. Supplementary Notes } \\
\hline \multicolumn{3}{|c|}{$\begin{array}{l}\text { 16. Abstract (Limit: } 200 \text { words) In this research report the concepts of learning and experience } \\
\text { are reviewed and their usefulness for predicting the future costs of solar technologiess } \\
\text { are evaluated. The literature review indicated that the cost estimates for solar } \\
\text { energy technologies are typically made assuming a fixed production process, character- } \\
\text { ized by standard capacity factors, overhead, and labor costs. The learning curve is } \\
\text { suggested as a generalization of the costs of potential solar energy systems. The } \\
\text { concept of experience is too ambiguous to be useful for cost estimation. There is no } \\
\text { logical reason to believe that costs will decline purely as a function of cumulative } \\
\text { production, and experience curves do not allow the analyst to identify logical sources } \\
\text { pf cost reduction directiy. The procedures for using learning and aggregated cost } \\
\text { curves to estimate the costs of solar technologies are outlined. It is recommended } \\
\text { that production histories of analogous products and processes are analyzed and the } \\
\text { learning and cost curves for these surrogates are estimated. These curves, if judged } \\
\text { applicable, can be used to predict the cost reductions in manufacturing solar } \\
\text { mergy technologies. }\end{array}$} \\
\hline \multicolumn{3}{|c|}{$\begin{array}{l}\text { a. Descriptors Cost ; Estimation ; Production ; Labor ; Learning ; Solar Energy ; } \\
\text { Technology ; Learning Curves ; Experience ; Experience Curves }\end{array}$} \\
\hline \multicolumn{3}{|c|}{$\begin{array}{l}\text { c. UC Categories } \\
\text { UC- } 60,62 a-e, 63,64\end{array}$} \\
\hline \multicolumn{2}{|c|}{$\begin{array}{l}\text { 18. Availability Statement } \\
\text { NTIS U. S. Department of Commerce } \\
5285 \text { Port Royal Road } \\
\text { Springfield, VA } 22161\end{array}$} & \begin{tabular}{|l|}
19. No. of Pages \\
34 \\
20. Price \\
$\$ 4.50$
\end{tabular} \\
\hline
\end{tabular}

